\section{Inactivation of Microcystis aeruginosa by Continuous Electrochemical Cycling Process in Tube Using $\mathrm{Ti} / \mathrm{RuO}_{2}$ Electrodes}

\author{
WENYAN LIANG, ${ }^{\dagger,}$, JIUHUI QU, $,^{*}, \dagger$ \\ LIBIN CHEN, ${ }^{\ddagger} \mathrm{HUIJUAN} \mathrm{LIU}^{\dagger}{ }^{\dagger}$ AN D \\ PENGJU LEI ${ }^{\dagger}$
}

State Key Laboratory of Environmental Aquatic Chemistry, Research Center for Eco-Environmental Science, Chinese Academy of Science, Beijing 100085, China, and College of Natural Resources \& Environment, Beijing Forestry University, Beijing 100083, China

Algae in waters often bring about influence in drinking water supplies. In this study, an electrochemical tube employing titanium coated with $\mathrm{RuO}_{2}$ as anode was constructed for inactivation of cyanobacteria (often called bluegreen algae) Microcystis aeruginosa. Suspensions containing $M$. aeruginosa $\left(2-4 \times 10^{9} \mathrm{~L}^{-1}\right)$ were exposed to current densities ranging from 1 to $10 \mathrm{~mA} \mathrm{~cm}^{-2}$ in a detention time of $52 \mathrm{~min}$. The variations of cell density, chlorophyll$a$, optical density, $\mathrm{pH}$, and conductivity were examined during the treatment. After 3.5 min the population of $M$. aeruginosa dropped rapidly and was reduced from $3 \times 10^{9}$ to $0.6 \times 10^{9} \mathrm{~L}^{-1}$ after $52 \mathrm{~min}$ at current densities from 5 to $10 \mathrm{~mA} \mathrm{~cm}{ }^{-2}$. The cell density and optical density of $M$. aeruginosa decreased proportionally to the current density and the detention time. Scanning electron microscopy investigation of algae revealed surface damage and apparent leakage of intracellular contents after electrochemical cycling process. Due to the damage of cells, the chlorophyll-a released from the cells was degraded by electrochemical oxidation. The removal rate of chlorophyll-a could reach $96 \%$ at the current density of $10 \mathrm{~mA} \mathrm{~cm}^{-2}$. Electrochemical treatment caused minor variation of $\mathrm{pH}$ values and conductivity of the suspensions. After electrochemical cycling processes, the optical density at $680 \mathrm{~nm}$ of algal cell suspensions remained below 0.1 after 6 days, and it showed that cells had no potential to survive and grow. The results implicated that the inactivation of $M$. aeruginosa was successfully performed by the electrochemical treatment, and it made the algal cells lose ability to survive, demonstrating the potential of such an alternative process for efficient water purification.

\section{Introduction}

Under certain conditions, usually a combination of high nutrient load and warm, stable conditions, algae (e.g., bluegreen algae (cyanobacteria)) can grow excessively and form blooms. These blooms are harmful to wildlife, domestic livestock, and human consumers, causing animal poisoning

\footnotetext{
* Corresponding author phone: +86-010-62849151; fax: +86-01062923558; e-mail: jhqu@mail.rcees.ac.cn.

${ }^{\dagger}$ Chinese Academy of Science.

‡ Beijing Forestry University.
}

and a range of human allergic and gastroenteric reactions (1). Algal-related problems in drinking water supplies have often referred to the fact that algae, and their extracellular products interfere with physical and/or chemical water purification processes. When algae passed through purification systems, they resulted in water of aesthetically unacceptable quality. Algae not only produce neuro- and hepatoxins that could be detrimental to the consumer's health but also produce algal products that can act as trihalomethane precursors and a source of nutrients for microbiological and other heterotrophic growth (2). When algae-laden waters are treated by direct filtration, algae can pass through filters and rapidly clog filters, even when the coagulation and sedimentation processes remove more than $90 \%$ of the algae in the influent (3). Due to algal penetration through filters and rapid filter clogging, it is not advisable to apply direct filtration to raw waters with very high algal concentration (4).

Application of copper sulfate remains the most commonly used method for controlling nuisance algae in lakes and reservoirs. But copper treatments can result in potentially high levels of $\mathrm{Cu}$ in the surface waters, accumulation of copper in the sediments, and possible chronic sediment and water quality problems (5). So, in drinking water treatment, preoxidation and/or postoxidation are often used to inactivate the algae. The chemicals such as chlorine, chlorine dioxide (2), ozone $(1,6,7)$, potassium permanganate $(8)$, or hydrogen peroxide (8) could be used as oxidants to treat these water quality problems. These oxidants do not physically eliminate algal cells but favor the oxidation process, thus inactivating any algae that survive the preceding treatment phases and their metabolites (7). They are not only used to control algae but also used as aids for the oxidation of natural and synthetic organics, oxidation of inorganics, color removal, and taste and odor control $(9,10)$. Preoxidation also improved treatment efficiency by reducing turbidity (8). All these results indicate oxidation is important for algal control in drinking water purification.

In recent years, electrochemical oxidation has become a new alternative for water treatment, replacing the traditional processes because it is relatively economical and has higher treatment efficiency. The use of electrochemical methods has been proved to be effective to reduce significantly the amount of pollutants present in highly colored industrial wastewater, particularly when the wastewater contains biorefractory organic pollutants or microtoxic substances $(11,12)$. The degradation of humic substances in the treatment of natural water for drinking water production by electrooxidation with $\mathrm{Ti} / \mathrm{Ru}_{0.3} \mathrm{Ti}_{0.7} \mathrm{O}_{2}$ electrode also had a good performance after approximately $2 \mathrm{~h}$ of electrolysis at $40 \mathrm{~mA}$ $\mathrm{cm}^{-2}$ (13).

Moreover, electrolytic methods have shown promise as a method of disinfection whereby low levels of free chlorine, sodium hypochlorite, or hypochlorous acid may be produced in situ in $\mathrm{NaCl}$-containing solutions. Cryptosporidium parvum oocysts and Clostridium perfringens spores are very resistant to chlorine and other drinking water disinfectants. Venczel et al. (14) used an electrochemical disinfection system that produced mix - oxidant containing free chlorine, chlorine dioxide, hydrogen peroxide, ozone, and other short-lived oxidants to achieve a $99.9 \%$ inactivation of the two microorganisms in $4 \mathrm{~h}$. The mix-oxidant solution displayed considerably more effectiveness than free chlorine in inactivation. When constant potentials were $>0.7 \mathrm{~V}$ versus a saturated calomel electrode (SCE) in a carbon-cloth electrochemical reactor or $>0.8 \mathrm{~V}$ versus an SCE in an electrochemical carbon fibers reactor, Escherichia coli, in drinking 
TABLE 1. Composition of Algal Growth Media MA

\begin{tabular}{|c|c|c|c|}
\hline components & $\begin{array}{c}\text { concn in } \\
\text { nutrient } \\
\text { media } \\
\left(\mathrm{mg} \mathrm{L}^{-1}\right)\end{array}$ & components & $\begin{array}{c}\text { concn in } \\
\text { nutrient } \\
\text { media } \\
\left(\mathrm{mg} \mathrm{L}^{-1}\right)\end{array}$ \\
\hline $\mathrm{NaNO}_{3}$ & 50 & $\mathrm{ZnCl}_{2}$ & 0.5 \\
\hline $\mathrm{KNO}_{3}$ & 100 & $\mathrm{CoCl}_{2} \cdot 6 \mathrm{H}_{2} \mathrm{O}$ & 5 \\
\hline $\mathrm{Ca}\left(\mathrm{NO}_{3}\right)_{2} \cdot 2 \mathrm{H}_{2} \mathrm{O}$ & 50 & $\mathrm{Na}_{2} \mathrm{MoO}_{4} \cdot 2 \mathrm{H}_{2} \mathrm{O}$ & 0.8 \\
\hline $\mathrm{Na}_{2} \mathrm{SO}_{4}$ & 40 & $\mathrm{H}_{3} \mathrm{BO}_{3}$ & 20 \\
\hline $\mathrm{MgCl}_{2} \cdot 6 \mathrm{H}_{2} \mathrm{O}$ & 50 & bicine & 500 \\
\hline $\mathrm{Na}_{2}$ EDTA & 5 & $\beta$-glycerophosphate & 100 \\
\hline $\mathrm{FeCl}_{3} \cdot 6 \mathrm{H}_{2} \mathrm{O}$ & 0.5 & $\mathrm{pH}$ & 8.6 \\
\hline $\mathrm{MnCl}_{2} \cdot 4 \mathrm{H}_{2} \mathrm{O}$ & 5 & & \\
\hline
\end{tabular}

water was killed to $<5 \%$ survival $(15,16)$. Similarly, the disinfection of Bacillus subtilis and Saccharomyces cerevisiae in drinking water by direct electrolysis worked efficiently even with low chloride concentrations in the treated water (17).

Besides the disinfection of human water supplies, bactericidal electrochemical treatment has been proposed for a variety of applications. The electrolytic water treatment system could be used for disinfection of seawater used in disease-prone high-intensity aquaculture systems and the bacterial populations of the pathogens Vibrio anguillarum and $V$. parahaemolyticus were completely inactivated (18, 19). When $0.33 \mathrm{~A}$ of direct current was applied, the surviving fraction of bacteria B. subtilis, E. coli, S. aureus, and Pseudomonas aeruginosa on bioreactor decreased to $1 \%$ after $1 \mathrm{~h} \mathrm{(20)}$. The Legionella bacteria, which are thought to be a source of disease in cooling towers and hot-water systems, decreased from $3.4 \times 10^{2}$ to $1.7 \times 10^{0} \mathrm{cfu}$ per $100 \mathrm{~mL}$ at 1.0 $\mathrm{kV}$, and they were not detected at $1.5 \mathrm{kV}(21)$. Electrochemical treatment even had a good effect in clinical practice for the disinfection of the ocular surface (22). However, the effect and duration time required for sterilization varied with the microorganisms, and this may be due to differences in their structures (20). For example, it took only $5 \mathrm{~min}$ for the population of $E$. coli to fall beneath the detection limit of the culturable count methodology, but bacteriophage P. aeruginos $a$ were able to tolerate greater direct current magnitudes and greater durations of exposure to direct current than bacteria (23).

There are only a few published studies regarding the inactivation of algae by electrochemical oxidation for water treatment. Feng et al. (24) studied algal inactivation by an electrochemical treatment system which was constructed by the $\mathrm{Ti} / \mathrm{RuO}_{2}-\mathrm{TiO}_{2}$, Pt, or Ti electrode. The chlorophyll- $a$ in natural water after treatment by the electrochemical system was almost totally removed from 270 to $0.6 \mu \mathrm{g} \mathrm{L} \mathrm{L}^{-1}$ by electrochemical inactivation and coagulation (24). But no more details were studied.

The objectives of this research were to verify the effectiveness of electrochemical water treatment systems on algal inactivation; to show the influence of processing factors such as current density and detention time on the algal viability; and to observe the variation of $\mathrm{pH}$, conductivity, cell density, and chlorophyll- $a$ values during the treatment and the growth situation of algae cells after treatment.

\section{Materials and Methods}

Algal Culture. The alga used in this research was Microcystis aeruginosa FACHB 496, a bluegreen alga commonly found in freshwater. M. aeruginosa was cultured in the late log growth phase that corresponded to 14 days after inoculation in batch mode in $500 \mathrm{~mL}$ Erlenmeyer flasks containing 200 $\mathrm{mL}$ of the sterilized growth media MA (see Table 1). The flasks were housed in a chemostat at $30^{\circ} \mathrm{C}$ under illumination

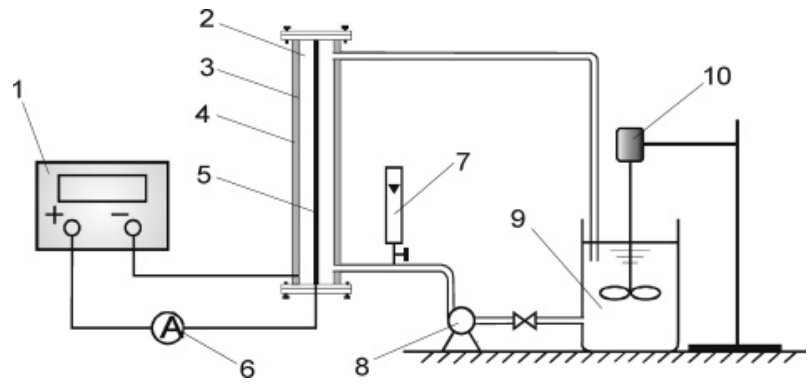

FIGURE 1. Schematic view of the electrochemical tubular apparatus: (1) DC power source; (2) tubular reactor; (3) cathode; (4) insulated layer; (5) anode; (6) ampere meter; (7) flow meter; (8) peristaltic pump; (9) reservoir; (10) stirring apparatus.

(28 $\mu \mathrm{mol} \mathrm{m} \mathrm{m}^{-2} \mathrm{~s}^{-1}$ ) on a 14-h light/10-h dark cycle. Growth was monitored daily by particle counting. Stock cultures were prepared weekly by aseptic transfer of a known number of algal cells from a culture in the log growth phase to a freshly sterilized flask with growth media.

Apparatus. As shown in Figure 1, the tubular electrochemical apparatus consisted mainly of a power supply, rod anode and tubular cathode, peristaltic pump, and reservoir. There have been a few studies focused on a tubular reactor. Körbahti and Tanyolaç (12) used the continuous tubular reactor for phenol removal through electrochemical oxidation, and it was realized with good efficiency. It was known that the efficiency of electrochemical water disinfection can be enhanced by using a divided electrolytic cell, because a separator prevents the reduction of the oxidizing species $\left(\mathrm{OH}^{*}, \mathrm{Cl}_{2}\right)$ on the cathode. But it seemed more practical to use an undivided electrolyzer (17). In this study, a common water pipe constructed from iron (i.d. $=17 \mathrm{~mm}$, length $=$ $260 \mathrm{~mm}$ ) with insulated material around it was used as the cathode and reactor with the volume of $59 \mathrm{~cm}^{3}$, while the anode was a commercial rod $(D=5 \mathrm{~mm})$ of titanium coated with $\mathrm{RuO}_{2}$. The anode was placed at the center of the reactor. The distance between cathode and anode was $6 \mathrm{~mm}$. A constant voltage/current controlled direct current (DC) power source was used as the power supply. A peristaltic pump was used to pump the algae-laden sample feed from the reservoir into the tubular reactor.

Cell Density. Algae cells were counted on a compound microscope in the counting chamber after preservation in Lugol's iodine. Cell counts were carried out according to the method used by Burrini et al. (7).

Chlorophyll-a. The samples were filtered through GF/C filter papers under low vacuum, and the chlorophylls were extracted using $5 \mathrm{~mL}$ of $90 \%$ acetone. The optical densities (OD) of the extracts at 750,663, 645, and $630 \mathrm{~nm}$ were determined using a U-3100 ultraviolet spectrophotometer (Hitachi Co., Japan) with $1 \mathrm{~cm}$ matched cells. The chlorophyll- $a$ concentrations were calculated using the equations given by the Chinese National Standard methods (25):

$$
\begin{aligned}
& \text { chlorophyll- } a\left(\mathrm{mg} \mathrm{L}^{-1}\right)=\left[11.64\left(A_{1}-A_{4}\right)-\right. \\
&\left.2.16\left(A_{2}-A_{4}\right)+0.10\left(A_{3}-A_{4}\right)\right] v / v_{\mathrm{g}}
\end{aligned}
$$

where $A_{1}, A_{2}, A_{3}$, and $A_{4}$ are the absorbance at $663,645,630$, and $750 \mathrm{~nm}$, respectively; $v$ is the volume of the extract (5 $\mathrm{mL})$; and $v_{\mathrm{g}}$ is the volume of filtered water.

Other Water Quality Parameters. The $\mathrm{pH}$ of the samples was measured using an Orion $720 \mathrm{pH}$ meter with a combined pH electrode (Orion Research Inc., USA). Calibration was carried out with $\mathrm{pH} 6.86$ and $\mathrm{pH} 4.13$ buffers. Optical densities of algae were measured spectrophotometrically at $680 \mathrm{~nm}$ $\left(\mathrm{OD}_{680}\right)$ using the U-3100 UV spectrophotometer (Hitachi 
Co., Japan). The conductivities of the samples were measured using a Hand C0150 conductivity meter (Loveland Co., Japan).

SEM. The effect of electrochemical cycling process on the morphology of algae has been examined with highresolution scanning electron microscopy (SEM) (FEI Quanta 200). Raw water samples before and after electrochemical cycling process were centrifuged. After that, the examined material was fully hydrated with a CPC030 critical point dryer to provide preparation and observation artifacts. Then the samples for SEM analysis were sputter coated with gold by a SCD005 sputter coater.

Statistical Analysis. To evaluate the significance of electric current density and detention time on cell density and other parameters, the authors performed an analysis of variance (ANOVA) using SPSS 12.0 Statistical Software (SPSS Inc., Chicago, IL). To assess the significance of difference between groups, the effects of current density and detention time over the course of an experiment were used to compare the $\mathrm{pH}$, conductivity, and other values by multifactor analysis of variance followed by least significant difference (LSD). Twoway ANOVA was used to evaluate the interaction between current density and detention time. Results of all tests were considered significant at $95 \%$ confidence if $P<0.05$ for a given $F$ statistic test value.

Experimental Procedure. To investigate the efficiency of electrochemical activities, galvanostatic electrolysis was performed in the algal solution, which contained $2 \times 10^{9}-4$ $\times 10^{9} \mathrm{~L}^{-1}$ cells. A batch of $M$. aeruginosa culture in the late log growth phase was concentrated by centrifugation at 3000 rpm for $5 \mathrm{~min}$. The concentrate was then mixed with fresh culture media to make up a total of 1.2 L. The algal suspension was then transferred into 3 polyethylene bottles $(600 \mathrm{~mL}$ each) and left overnight in the chemostat at $30{ }^{\circ} \mathrm{C}$ under illumination $\left(28 \mu \mathrm{mol} \mathrm{m} \mathrm{m}^{-2} \mathrm{~s}^{-1}\right)$ on a 14 -h light/10-h dark cycle.

A total of $600 \mathrm{~mL}$ of algal water was poured into the reservoir and fed to the column to fill it completely and then recycled with the application of the specified current and voltage. To study the effect of current density of the electrochemical cycling process on cell viability, the algal suspensions were exposed to the current densities ranging from 1 to $10 \mathrm{~mA} \mathrm{~cm}^{-2}$. To study the effect of detention time on viability, the suspension was continuously exposed to different direct currents. At appropriate time intervals, 100 $\mathrm{mL}$ samples were taken from the reservoir for analysis to determine the cell density, chlorophyll- $a, \mathrm{OD}_{680}, \mathrm{pH}$, and conductivity of the reaction medium during electrochemical conversion. The initial samples of $100 \mathrm{~mL}$ without any treatment were taken from the reservoir as the control samples.

The efficiency of the electrochemical cycling process in killing microorganisms was often expressed as the percentage survival of cells after the oxidation process had been stopped. As indirect indicators of biomass, chlorophyll- $a$ and $\mathrm{OD}_{680}$ were used in the study. However, dying cells would still contain chlorophyll- $a$, which would be measured together with that in viable cells in a chlorophyll- $a$ extraction that was carried out directly after the oxidation process had been ceased. The net efficiency of the treatment to kill algae could therefore be masked (2). It is also important to know how electrochemical oxidation affects the potential of cells to grow in the purification plant after they have survived oxidation. Algal cells were therefore subjected to optimal light and temperature conditions, which were $30^{\circ} \mathrm{C}$ under illumination (28 $\mu \mathrm{mol} \mathrm{m}^{-2} \mathrm{~s}^{-1}$ ) on a 14 -h light/10-h dark cycle, for 2 , 4 , and 6 days after the oxidation reaction was stopped. Control samples to which no electrochemical was treated were also exposed to the same conditions as the test samples. All the experiments were performed in triplicate, and average results are presented in the figures.

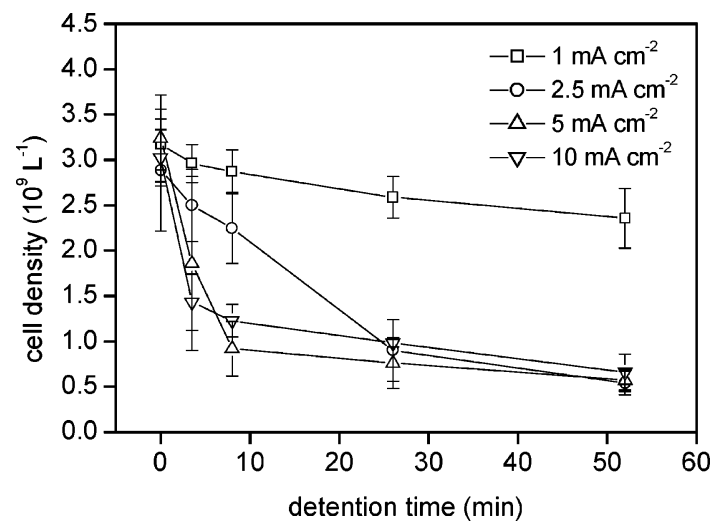

FIGURE 2. Effect of current density and detention time on $M$. aeruginosa cell density by electrochemical cycling process. The results shown are mean data from triplicate experiments, and error bars indicate standard deviations.

\section{Results and Discussion}

Cell Density Change. Algae cell density in disinfected samples was determined for each time point, including zero time. The initial cell density of $M$. aeruginosa was $2-4 \times 10^{9} \mathrm{~L}^{-1}$, the mean of the control samples measured at zero time and at the end of the experiment.

As shown in Figure 2, the cell density of $M$. aeruginosa decreased proportionally to the current density and the detention time, which was in agreement with the results obtained by Guillou and Murr (26) on inactivation of $S$. cerevisiae by electric treatment. It was obvious that the electrochemical inactivation began to be observed at current density $\geq 2.5 \mathrm{~mA} \mathrm{~cm}{ }^{-2}$. After $8.0 \mathrm{~min}$ of treatment, the population of $M$. aeruginosa treated with direct electric current at $2.5 \mathrm{~mA} \mathrm{~cm}^{-2}$ decreased sharply, but after only 3.5 min the population of $M$. aeruginosa dropped rapidly with a current density from 5 to $10 \mathrm{~mA} \mathrm{~cm}$. The lysis of algal cells led to the decrease of cell density after electrochemical treatment. No temperature change could be observed through the whole range of experimental settings used, even at $10 \mathrm{~mA} \mathrm{~cm}$-2 and $52 \mathrm{~min}$. The ANOVA analysis was performed on the cell densities from tests processed under electrolysis at $1-10 \mathrm{~mA} \mathrm{~cm}^{-2}$. The effect of current densities on the cell densities induced by electrolysis was found to be significant at these current densities $(F=41.50, P<0.05)$. Statistical analyses also showed that the cell densities varied significantly with detention time of exposure $(F=54.63, P$ $<0.05)$. But between the current densities of 5 and $10 \mathrm{~mA}$ $\mathrm{cm}^{-2}$, the effect of current density on the cell densities was not significant $(P=0.968>0.05)$. The statistical results indicated that the cell density varied significantly with the current density and detention time.

The impact of electric current on the viability of $M$. aeruginosa was confirmed by SEM. Fresh M. aeruginosa cells receiving no electrochemical treatment were full with some excreted substances on the surfaces (Figure 3a). After treatment, surface damage was observed (Figure 3b). More importantly, a certain amount of cellular materials was released from the disinfected cells. Electrochemical process could produce intermediate chemical species such as free radicals, which have oxidizing potentials higher than that of chlorine or even ozone. These strong oxidants could attack the cell membrane and wall, disrupt membrane integrity, or electrolyze the molecules in the cell surface, which brought massive cell kills and lyses $(27,28)$.

Although these results have significant implications, the underlying mechanism of microbial inactivation remains unclear. There is general agreement that very little is known about what really occurs in the cell and its membranes at the molecular level after exposure to electric current. Several 
(a)

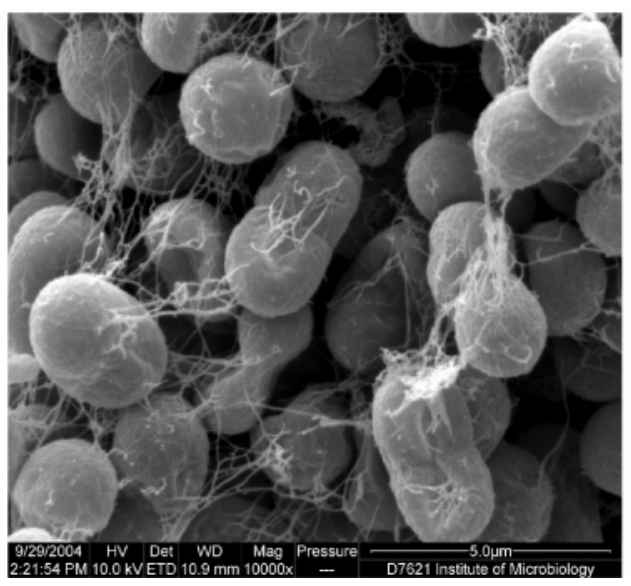

(b)

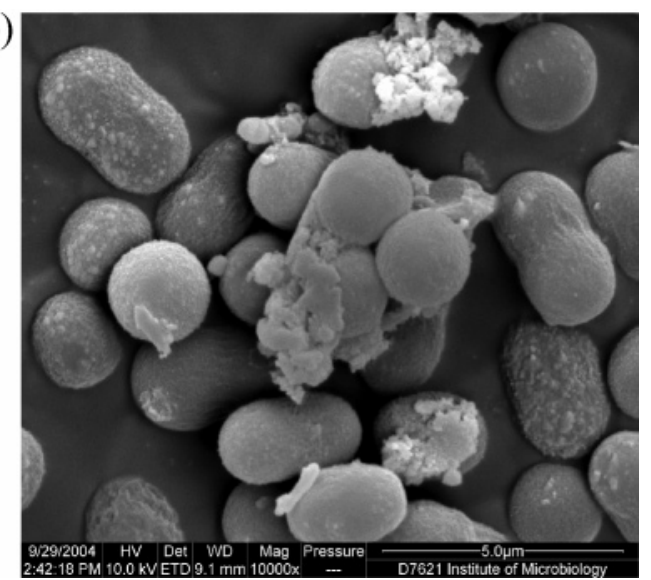

FIGURE 3. Scanning electron micrographs of $\boldsymbol{M}$. aeruginosa before (a) and after (b) electrochemical cycling process.

mechanisms have been proposed to account for the lethality of electrochemical exposure, one of which is electron transfer. Matsunaga et al. $(15,16)$ established that the electrochemical destruction of microbial cells was based on the direct electron transfer between cells and the electrode and demonstrated that coenzyme A was oxidized to dimeric coenzyme A. Thus, electricity may directly oxidize cellular constituents, leading to cell death. They also showed that the resulting microbial cell death was due to the inhibition of respiratory activity.

Most of studies suggested that the cell death is caused by oxidative stress or due to electrochemically generated oxidants. The anodic discharge of the water or chlorides takes place forming hydroxyl radicals or chlorohydroxyl radicals, which are absorbed on the active sites of the electrode surface $\mathrm{M} \cdot$ (reactions 1 and 2). The free chlorine is formed according to reaction 3 , and the free chlorine produced is under equilibrium with $\mathrm{OCl}^{-}$ion in reaction 4 . At the same time, chlorine dioxide, hydrogen peroxide, and ozone are found among the oxidants produced from the electrolysis of solutions according to reactions 5-7 (29).

$$
\begin{gathered}
\mathrm{H}_{2} \mathrm{O}+\mathrm{M}^{\bullet} \rightarrow \mathrm{M}\left[\mathrm{OH}^{-}\right]+\mathrm{H}^{+}+\mathrm{e}^{-} \\
\mathrm{H}_{2} \mathrm{O}+\mathrm{M}^{\bullet}+\mathrm{Cl}^{-} \rightarrow \mathrm{M}\left[\mathrm{ClOH}^{-}\right]+\mathrm{H}^{+}+2 \mathrm{e}^{-} \\
\mathrm{H}_{2} \mathrm{O}+\mathrm{M}\left[\mathrm{ClOH}^{-}\right]+\mathrm{Cl}^{-} \rightarrow \mathrm{Cl}_{2}+\mathrm{M}^{\bullet}+\mathrm{O}_{2}+3 \mathrm{H}^{+}+4 \mathrm{e}^{-} \\
\mathrm{Cl}_{2}+2 \mathrm{OH}^{-} \rightarrow \mathrm{H}_{2} \mathrm{O}+\mathrm{OCl}^{-}+\mathrm{Cl} \\
\mathrm{H}_{2} \mathrm{O}+\mathrm{M}\left[\mathrm{ClOH}^{-}\right]+\mathrm{Cl}_{2} \rightarrow \\
\mathrm{M}^{\bullet}+\mathrm{ClO}_{2}+3 \mathrm{H}^{+}+2 \mathrm{Cl}^{-}+\mathrm{e}^{-} \\
\mathrm{O}_{2}+\mathrm{M}\left[\mathrm{OH}^{-}\right] \\
\mathrm{H}_{2} \mathrm{O}+\mathrm{M}^{\bullet}+\mathrm{O}_{3}+\mathrm{H}^{+}+\mathrm{e}^{-}
\end{gathered}
$$

The total concentration of hypochlorite ions, hypochlorous acid, and dissolved chlorine form an amount of active chlorine $(17,23)$. These oxidants have very strong oxidation potential. Venczel et al. (14) called the solution containing such oxidants a mixed-oxidant solution. A $5 \mathrm{mg} \mathrm{L}^{-1}$ dose of the mixed-oxidants produced substantial inactivation of Cryptosporidium oocysts with the reduction of $2.3 \mathrm{log}$ units after $4 \mathrm{~h}$ of exposure. Even without adding any chemicals, hydrogen peroxide produced by electrolysis using only two electrodes, a carbon felt cathode and a dimensional stabilized anode-titanium coated with $\mathrm{RuO}_{2}$, was effective for the disinfection (30). The adsorbed hydroxyl radicals that may

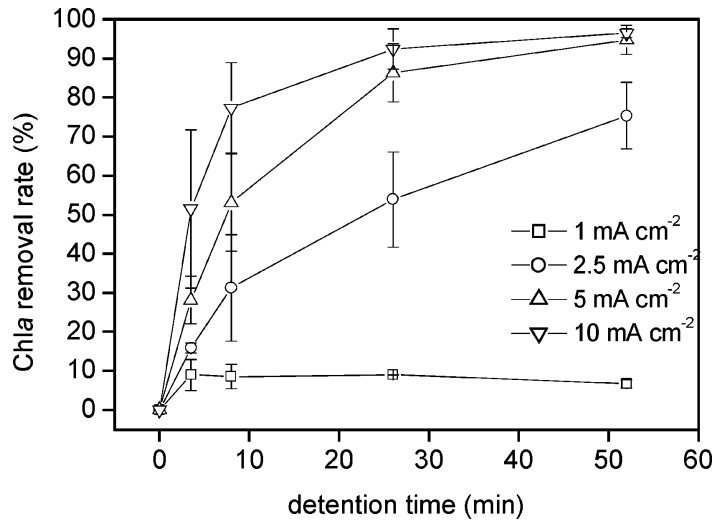

FIGURE 4. Effect of current density and detention time on chlorophyll-a removal by electrochemical cycling process. The results shown are mean data from triplicate experiments, and error bars indicate standard deviations.

form chemisorbed active oxygen can cause microorganism inactivation (24). But, the radicals formed during electrolysis were influenced significantly by the anode material. The hydroxyl radicals, which were formed at the $\mathrm{Ti} / \mathrm{RuO}_{2}-\mathrm{TiO}_{2}$ electrode, were larger than that at the Pt and Ti electrodes. Besides chlorine and hypochlorite, radicals and hydrogen peroxide may play an important role in inactivation due to the $\mathrm{Ti} / \mathrm{RuO}_{2}$ anode used in this study.

Chlorophyll-a Removal. Cyanobacteria have only one form of chlorophyll (chlorophyll- $a$ ), and they also have characteristic biliprotein pigments (phycobilins), which function as accessory pigments in photosysthesis. Phycocyan, a blue phycobilin, together with the green chlorophyll- $a$ are responsible for the blue green color of the cyanobacteria (31). In this study, the concentration of chlorophyll- $a$ was used as the biomass of $M$. aeauginos $a$ and the indirect measure of cell integrity.

The effect of electrochemical oxidation on the chlorophyll- $a$ removal was shown in Figure 4. Chlorophyll- $a$ removal efficiency was increased to $75 \%, 95 \%$, and $96 \%$, as the applied current density was increased to $2.5,5$, and $10 \mathrm{~mA} \mathrm{~cm}^{-2}$, respectively, at $52 \mathrm{~min}$. But chlorophyll- $a$ removal efficiency was only $6.7 \%$ for $1 \mathrm{~mA} \mathrm{~cm}^{-2}$ at $52 \mathrm{~min}$. An ANOVA analysis indicated that the chlorophyll- $a$ removal efficiency varied very significantly with the current density $(F=144.785, P<$ $0.05)$ and the detention time $(F=142.092, P<0.05)$. Unlike the statistics results on the cell density, the effect of current density on the chlorophyll- $a$ removal was significant between 5 and $10 \mathrm{~mA} \mathrm{~cm}^{-2}$. It appeared that the chlorophyll- $a$ concentration of the algae cells did not correlate with the number of algae after electrochemical treatment. The results 


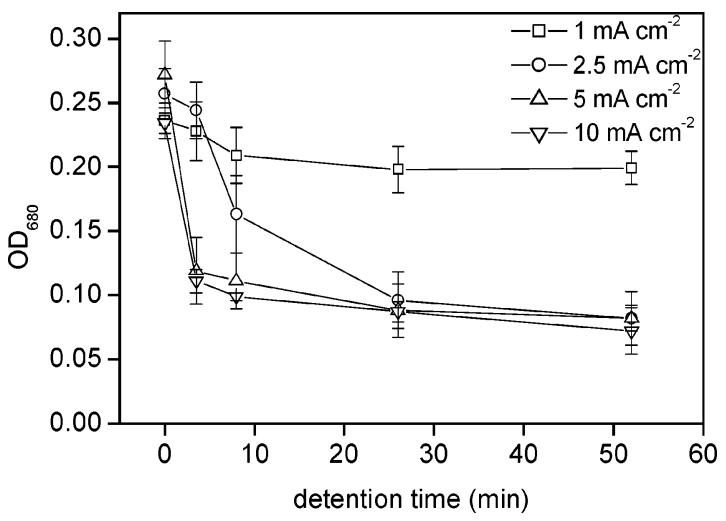

FIGURE 5. Effect of current density and detention time on $\mathbf{O D}_{680}$ of cell suspensions by electrochemical cycling process. The results shown are mean data from triplicate experiments, and error bars indicate standard deviations.

indicated that the electrochemical treatment caused deterioration of the cell integrity and components of algal cells. The chlorophyll- $a$ released from the cells was degraded by the electrochemical oxidation. After a period time of treatment, nearly all of the chlorophyll- $a$ was oxidated at 5 or 10 $\mathrm{mA} \mathrm{cm}^{-2}$, but some algal cells remained even if they contained no chlorophyll- $a$ in the cells. This was similar to the results of treatment by ozone oxidation (1) and copper sulfate on algae inactivation (32)

$\mathbf{O D}_{680}$ Variation of the Solution. To know whether the remaining algal cells had the potential to survive and grow, the cell suspensions after electrochemical cycling process were subjected to optimal light and temperature conditions for 6 days to observe the $\mathrm{OD}_{680}$ variation that was used as the indirect index of cell viability (33). $\mathrm{OD}_{680}$ is the optical density of algal culture suspension at $680 \mathrm{~nm}$, which is the maximal absorbance band of $M$. aeruginosa cell suspensions.

Figure 5 shows the effect of current density and detention time on the $\mathrm{OD}_{680}$ variation of the algal cell suspensions.
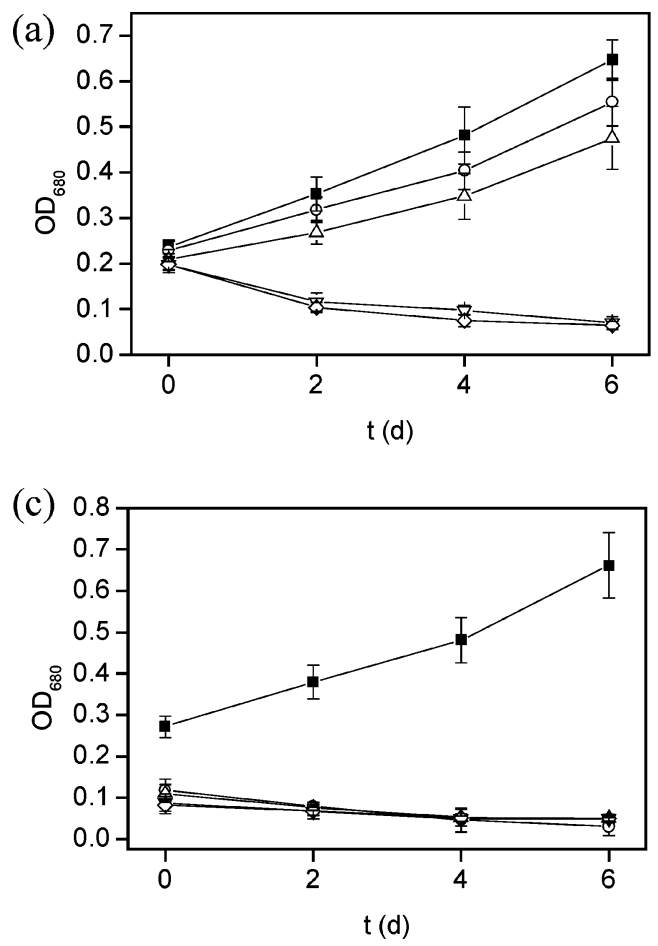

During the electrochemical cycling process for the current

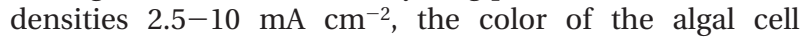
suspensions changed from green to yellow-green and finally to yellow due to the degradation of chlorophyll- $a$. Only for $1 \mathrm{~mA} \mathrm{~cm}{ }^{-2}$ did the color remain green for the duration of 52 min. From the $\mathrm{OD}_{680}$ values and chlorophyll- $a$ removal rates at current density of $1 \mathrm{~mA} \mathrm{~cm}^{-2}$, it might be concluded that the algae were still alive and could grow. However, after the electrochemical oxidation was stopped, the $\mathrm{OD}_{680}$ variation of the culture algae during 6 days gave more information about the cell viability (shown in Figure 6). The algae treated for $3.5 \mathrm{~min}$ to $8.0 \mathrm{~min}$ by $1 \mathrm{~mA} \mathrm{~cm}{ }^{-2}$ still could grow, and the $\mathrm{OD}_{680}$ had an increasing trend as the control sample. But the $\mathrm{OD}_{680}$ of the algal samples treated for $26 \mathrm{~min}$ to $52 \mathrm{~min}$ dropped gradually in 6 days. After 6 days, the $\mathrm{OD}_{680}$ values were close to those of algae that were treated by 5 or $10 \mathrm{~mA}$ $\mathrm{cm}^{-2}$. It indicated that the algae could be inactivated even at the low current density of $1 \mathrm{~mA} \mathrm{~cm}^{-2}$ if the sample had been treated for enough time. The ANOVA analysis also revealed that the effect of exposure time of electrochemical cycling process was significant on the $\mathrm{OD}_{680}$ variation for the current density of $1 \mathrm{~mA} \mathrm{~cm}^{-2}(F=225.083, P<0.05)$ and 2.5 $\mathrm{mA} \mathrm{cm}^{-2}(F=379.591, P<0.05)$. But, for the current density of 5 and $10 \mathrm{~mA} \mathrm{~cm}^{-2}$, the effect of exposure time was not significant on the $\mathrm{OD}_{680}$ between 3.5 and $52 \min (F=0.804$, $P=0.501>0.05$ for $5 \mathrm{~mA} \mathrm{~cm}{ }^{-2} ; F=2.379, P=0.088>0.05$ for $10 \mathrm{~mA} \mathrm{~cm}^{-2}$ ). That the $\mathrm{OD}_{680}$ decreased or remained at low values showed that the algae lost the ability to survive and grow. Under these conditions, the M. aeruginosa were entirely inactivated within $52 \mathrm{~min}$ by all of the current density settings used. At a current density of 5 or $10 \mathrm{~mA} \mathrm{~cm}^{-2}$, it took only $3.5 \mathrm{~min}$ for $M$. aeruginosa to be fully inactivated.

Variation of the Solution pH. Production of $\mathrm{H}^{+}$and $\mathrm{OH}^{-}$ by the electrolysis of water may generate modifications in the $\mathrm{pH}$ of cell suspensions. Figure 7 showed the $\mathrm{pH}$ variation by electrolysis. However, measurements of $\mathrm{pH}$ in the algal suspensions before and after the electrochemical cycling process showed that little change in $\mathrm{pH}$ was induced by
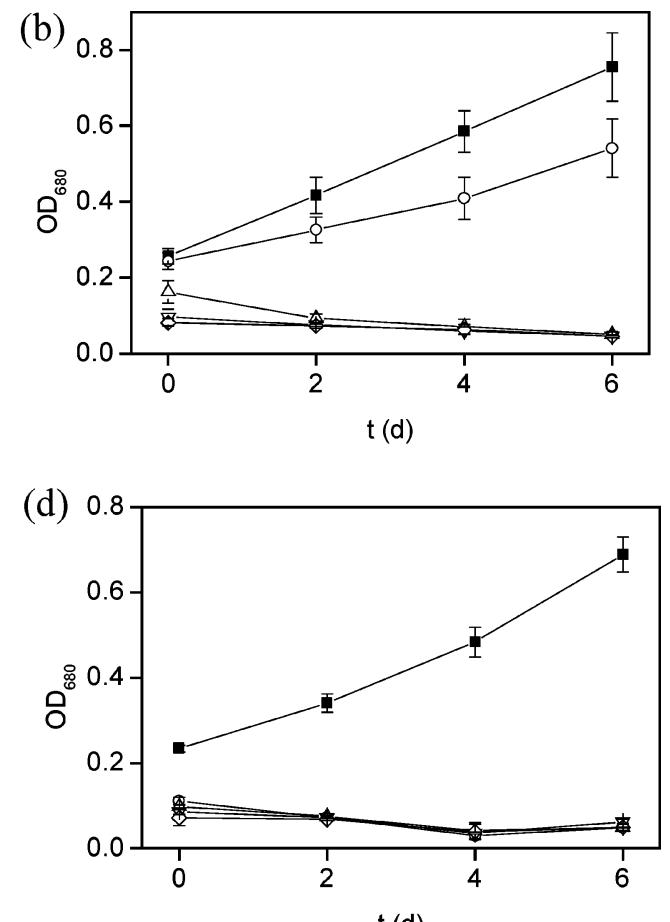

$t(d)$

FIGURE 6. $\mathrm{OD}_{680}$ variation of the culture algae after (a) 1, (b) 2.5 , (c) 5 , and (d) $10 \mathrm{~mA} \mathrm{~cm} \mathrm{~cm}^{-2}$ electrochemical cycling processes. Symbols of detention time of continuous electrochemical process: $(\square)$ control sample; $(O) 3.5 \mathrm{~min} ;(\Delta) 8.0 \mathrm{~min} ;(\nabla) 26 \mathrm{~min} ;(\diamond) 52 \mathrm{~min}$. Error bar $=$ standard deviations. 


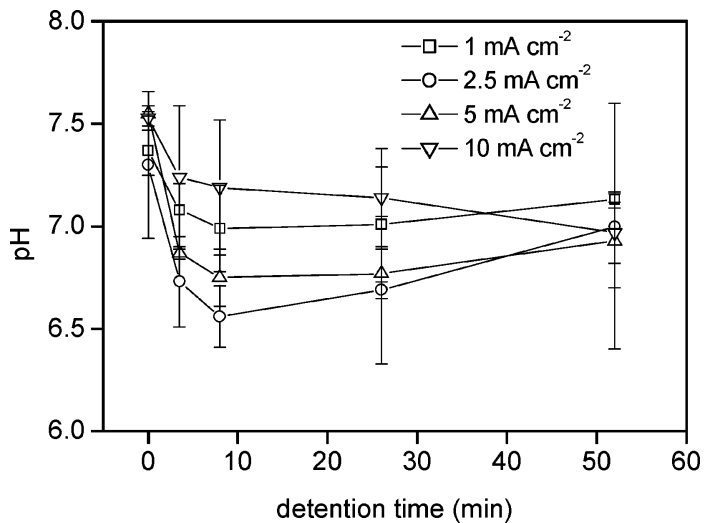

FIGURE 7. Effect of current density and detention time on $\mathrm{pH}$ of cell suspensions by electrochemical cycling process. The results shown are mean data from triplicate experiments, and error bars indicate standard deviations.

electrolysis. As a general trend, the $\mathrm{pH}$ values for all the samples taken after the beginning of the electrolysis dropped in proportion with the time and then reached a nearly constant value. After $52 \mathrm{~min}$, the $\mathrm{pH}$ increased a very little. The trend in $\mathrm{pH}$ can be explained by the products formed on both electrode surfaces. There was an occurrence of the water reduction with the consequent hydrogen evolution and an increase of the $\mathrm{pH}$ due to the formation of hydroxyl anions on the cathode. On the other hand, in the anodic surface the reactions including oxygen evolution, chlorine evolution, and organic oxidation occurred. In opposition to the hydroxyl formation in the cathodic side, there was the formation of $\mathrm{H}^{+}$species in the anodic side, which may decrease the $\mathrm{pH}$. This variation on the $\mathrm{pH}$ to lower values has not the same magnitude of the $\mathrm{pH}$ increasing in the cathodic side (13). When the products of the two electrodes were mixed together, the $\mathrm{pH}$ value decreased a little in about $3.5 \mathrm{~min}$ and then reached a constant value in algae inactivation process. The little increase of $\mathrm{pH}$ at the end of the treatment might result from the electrolysis of bicine, which was often used as biological buffer. Bicine or $\mathrm{N}, \mathrm{N}$-bis(2hydroxyethyl)glycine with the formula of $\left(\mathrm{CH}_{2} \mathrm{CH}_{2} \mathrm{OH}\right)_{2} \mathrm{NCH}_{2}-$ $\mathrm{COOH}$ could be electrolyzed and produced hydroxyl anions in the solution. An ANOVA analysis was performed on $\mathrm{pH}$ value under electrolysis at $1-10 \mathrm{~mA} \mathrm{~cm}$. The result of current density on the $\mathrm{pH}$ value induced by electrolysis was found to have no significance $(F=1.998, P=0.130>0.05)$ at these amperages. The influence of $\mathrm{pH}$ on algal viability was small. Guillou and Murr (26) found that no lethal effect of $\mathrm{pH}$ (from 5 to 8.5) was observed on the inactivation of yeast $S$. cerevisiae by electrolysis. It indicated that the inactivation of algae by electrolysis could not be attributed to local variation of $\mathrm{pH}$ as the yeast did.

Variation of the Solution Conductivity. Since the culture media contained many electrolytical substances and the feed streams contained the almost the same cell densities of algae, the conductivity of the cell suspensions was between 450 and $460 \mu \mathrm{S} \mathrm{cm}^{-1}$ (see Figure 8). Though the conductivity value was not very high, it was sufficient for the electrochemical oxidation treatment. The current densities for these treatments were set to $1-10 \mathrm{~mA} \mathrm{~cm}^{-2}$, and the voltage, in the range of 3.5-9.2 V, was applied for $52 \mathrm{~min}$. The conductivity of algal suspension after electrochemical treatment was observed to drop gradually with the detention time and then increased a little for the current density of 2.5, 5, and $10 \mathrm{~mA}$ $\mathrm{cm}^{-2}$. Only for the current density of $1 \mathrm{~mA} \mathrm{~cm}-2$ did the conductivity increase with the detention time. The reduction of conductivity was not proportional to the current density. An ANOVA indicated that the conductivity of cell suspensions varied significantly with the magnitude of applied direct

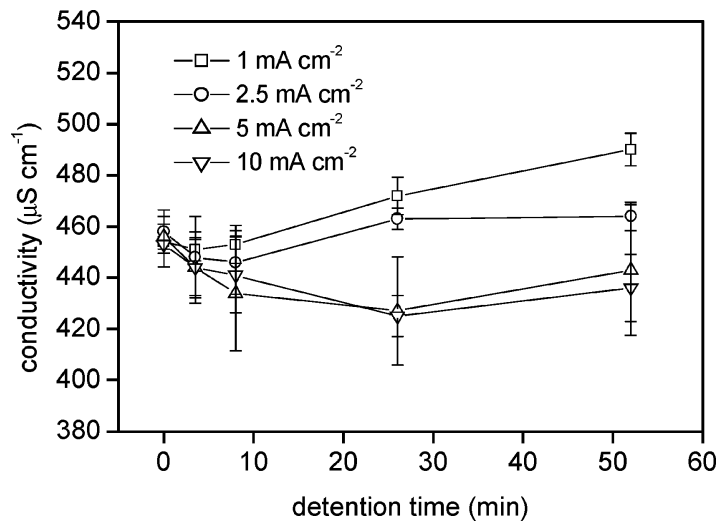

FIGURE 8. Effect of current density and detention time on conductivity of cell suspensions by electrochemical cycling process. The results shown are mean data from triplicate experiments, and error bars indicate standard deviations.

current $(F=12.926, P<0.05)$. The increases of the conductivity for 1 and $2.5 \mathrm{~mA} \mathrm{~cm}^{-2}$ indicated that the cells might be damaged after a period of time by the electrochemical treatment, and the released substances from the damaged cells changed the conductivity of the cell suspensions. In addition to the cell damage, the electrolysis of bicine could increase the conductivity of cell suspensions. Due to the large current density at 5 and $10 \mathrm{~mA} \mathrm{~cm}^{-2}$, the substances could be absorbed on the electrodes and resulted in the reduction of conductivity. A slight rise of conductivity at the end of the electrochemical cycling process could also result from the electrolysis of bicine as $\mathrm{pH}$ variation. However, the further reason of the conductivity variation should be studied in more detail.

\section{Acknowledgments}

This work was supported by grants from National Natural Science Foundation of China (Grant 50478115), National Science Fund for Distinguished Young Scholars (Grant 50225824), and National Natural Science Foundation of China (Grant 20337020). The authors of this work also want to express their acknowledgment to Dr. John Karlik from the University of California at Davis for his critical review and correction of the manuscript.

\section{Literature Cited}

(1) Benoufella, F.; Laplanche, A.; Boisdon, V.; Bourbigot, M. M. Elimination of Microcystis cyanobacteria (blue-green algae) by an ozoflotation process: a pilot plant study. Water Sci. Technol. 1994, 30 (8), 245-257.

(2) Steynberg, M. C.; Guglielmi, M. M.; Geldenhuys, J. C.; Pieterse, A. J. H. Chlorine and chlorine dioxide: pre-oxidants used as algocide in potable water plants. J. Water SRT-Aqua 1996, 45 (4), $162-170$.

(3) Himberg, K.; Keijola, A.-M.; Hiisvirta, L.; Pyysalo, H.; Sivonen, $\mathrm{K}$. The effect of water treatment processes on the removal of hepatotoxins from Microcystis and Oscillatoria cyanobacterial: a laboratory study. Water Res. 1989, 23 (8), 979-984.

(4) Petruševski, B.; Vlaški, A.; Breeman A. N. V.; Alaerts, G. J. Influence of algal species and cultivation conditions on algal removal in direct filtration. Water Sci. Technol. 1993, 27 (11), 211-220.

(5) Haughey, M. A.; Anderson, M. A.; Whitney, R. D.; Taylor, W. D.; Losee, R. F. Forms and fate of $\mathrm{Cu}$ in a source drinking water reservoir following $\mathrm{CuSO}_{4}$ treatment. Water Res. 2000, 34 (13), 3440-3452.

(6) Montiel, A.; Welté, B. Preozonation coupled with flotation filtration: successful removal of algae. Water Sci. Technol. 1998, 37 (2), 65-73.

(7) Burrini, D.; Lupi, E.; Klotzner, C.; Santini, C.; Lanciotti, E. Survey of microalgae and cyanobacteria in a drinking-water utility supplying the city of Florence, Italy. J. Water SRT-Aqua 2000, 49 (3), 139-147.

(8) Petruševski, B.; Breemen, A. N. V.; Alaerts, G. Effect of permanganate pre-treatment and coagulation with dual coagulants 
on algae removal in direct filtration. J. Water SRT-Aqua 1996, 45 (5), 316-326.

(9) Schmidt, W.; Hambsch, B.; Petzoldt, H. Classification of algogenic organic matter concerning its contribution to the bacterial regrowth potential and by-products formation. Water Sci. Technol. 1998, 37 (2), 91-96.

(10) Dietrich, A. M.; Hoehn, R. C.; Dufresne, L. C.; Buffin, L. W.; Rashash, D. M. C.; Parker, B. C. Oxidation of odorous and nonodorous algal metabolites by permanganate, chlorine, and chlorine dioxide. Water Sci. Technol. 1995, 31 (11), 223-228.

(11) Fernandes, A.; Morão, A.; Magrinho, M.; Lopes, A.; Gonçalves, I. Electrochemical degradation of C. I. Acid Orange 7. Dyes Pigm. 2004, 61, 287-296.

(12) Körbahti, B. K.; Tanyolaç, A. Continuous electrochemical treatment of phenolic wastewater in a tubular reactor. Water Res. 2003, 37, 1505-1514.

(13) Motheo, A. J.; Pinhedo, L. Electrochemical degradation of humic acid. Sci. Total Environ. 2000, 256, 67-76.

(14) Venczel, L. V.; Arrowood, M.; Hurd, M.; Sobsey, M. D. Inactivation of Cryptosporidium parvum oocysts and Clostridiu perfringens spores by a mixed-oxidant disinfectant and by free chlorine. Appl. Environ. Microbiol. 1997, 63 (4), 1598-1601.

(15) Matsunaga, T.; Nakasono, S.; Takamuku, T.; Burgess J. G.; Nakamura, N.; Sode, K. Disinfection of drinking water by using a novel electrochemical reactor employing carbon-cloth electrodes. Appl. Environ. Microbiol. 1992, 58 (2), 686-689.

(16) Matsunaga, T.; Nakasono, S.; Kitajima, Y.; Horiguchi, K. Electrochemical disinfection of bacteria in drinking water using activated carbon fibers. Biotechnol. Bioeng. 1994, 43, 429-433.

(17) Bergmann, H.; Iourtchouk, T.; Schöps, K.; Bouzek, K. New UV irradiation and direct electrolysis - promising methods for water disinfection. Chem. Eng. J. 2002, 85, 111-117.

(18) Jorquera, M. A.; Valencia, G.; Eguchi, M.; Katayose, M.; Riquelme, C. Disinfection of seawater for hatchery aquaculture systems using electrolytic water treatment. Aquaculture 2002, 207, 213224.

(19) Park, J. C.; Lee, M. S.; Lee, D. H.; Park, B. J.; Han, D. W.; Uzawa, M.; Takatori, K. Inactivation of bacteria in seawater by lowamperage electric current. Appl. Environ. Microbiol. 2003, 69 (4), 2405-2408

(20) Tokuda, H.; Nakanishi, K. Application of direct current to protect bioreactor against contamination. Biosci. Biotechnol. Biochem. 1995, 59 (4), 753-755.

(21) Feng, C.; Suzuki, K.; Zhao, S.; Sugiura, N.; Shimada, S.; Maekawa, T. Water disinfection by electrochemical treatment. Bioresour. Technol. 2004, 94, 21-25.
(22) Shimmura, S.; Matsumoto, K.; Yaguchi, H.; Okuda, O.; Miyajima, S.; Negi, A.; Shimazaki, J.; Tsubota, K. Acidic electrolysed water in the disinfection of the ocular surface. Exp. Eye Res. 2000, 70, $1-6$.

(23) Drees, K. P.; Abbaszadegan, M.; Maier, R. M. Comparative electrochemical inactivation of bacteria and bacteriophage Water Res. 2003, 37, 2291-2300.

(24) Feng, C.; Sugiura, N.; Shimada, S.; Maekawa, T. Development of a high performance electrochemical wastewater treatment system. J. Hazard. Mater. 2003, B103, 65-78.

(25) Yu, Y. X.; Wu G. Q.; Meng X. T. Manual for Microorganism Test in Environmental Engineering; China Environmental Science Press: Beijing, 1990 (in Chinese).

(26) Guillou, S.; Murr, N. E. Inactivation of Saccharomyces cerevisiae in solution by low-amperage electric treatment. J. Appl. $\mathrm{Mi}$ crobiol. 2002, 92, 860-865.

(27) Diao, H. F.; Li, X. Y.; Gu, J. D.; Shi, H. C.; Xie, Z. M. Electron microscopic investigation of the bactericidal action of electrochemical disinfection in comparison with chlorination ozonation and Fenton reaction. Process Biochem. 2004, 39, 1-6.

(28) Liu, W. K.; Brown, M. R. W.; Elliott, T. S. J. Mechanisms of the bactericidal activity of low amperage electric current (DC). J. Antimicrob. Chemother. 1997, 39, 687-695.

(29) Israilides, C. J.; Vlyssides, A. G.; Mourafeti, V. N.; Karvouni, G. Olive oil wastewater treatment with the use of an electrolysis system. Bioresour. Technol. 1997, 61, 163-170.

(30) Drogui, P.; Elmaleh, S.; Rumeau, M.; Bernard, C.; Rambaud, A. Oxidising and disinfecting by hydrogen peroxide producted in a two-electrode cell. Water Res. 2001, 35 (13), 3235-3241.

(31) Chow, C. W. K.; House, J.; Velzeboer, R. M. A.; Drikas, M.; Burch, M. D.; Steffensen, D. A. The effect of ferric chloride flocculation on cyanobacterial cells. Water Res. 1998, 32 (3), 808-814.

(32) Chow, C. W. K.; Drikas, M.; House, J.; Burch, M. D.; Velzeboer R. M. A. The impact of conventional water treatment processes on cells of the cyanobacterium Microcystis aeruginosa. Water Res. 1999, 33 (15), 3253-3262.

(33) Ma, J.; Lin, F.; Zhang, R.; Yu, W.; Lu, N. Differential sensitivity of two green algae, Scenedesmus quadricauda and Chlorella vulgaris, to 14 pesticide adjuvants. Ecotoxicol. Environ. Saf. 2004, 58, $61-67$.

Received for review October 17, 2004. Revised manuscript received April 1, 2005. Accepted April 4, 2005.

\section{ES048382M}

